Hall, Christopher J ORCID:

https://orcid.org/0000-0001-9038-1238 (2020) An ontological framework for English. In: Hall, Christopher J ORCID: https://orcid.org/0000-0001-9038-1238 and Wicaksono, Rachel ORCID: https://orcid.org/0000-0003-0312-8491, (eds.) Ontologies of English. Conceptualising the language for learning, teaching, and assessment. Cambridge, Cambridge University Press, pp. 13-36

Downloaded from: http://ray.yorksj.ac.uk/id/eprint/4232/

The version presented here may differ from the published version or version of record. If you intend to cite from the work you are advised to consult the publisher's version: https://doi.org/10.1017/9781108685153.002

Research at York St John (RaY) is an institutional repository. It supports the principles of open access by making the research outputs of the University available in digital form. Copyright of the items stored in RaY reside with the authors and/or other copyright owners. Users may access full text items free of charge, and may download a copy for private study or non-commercial research. For further reuse terms, see licence terms governing individual outputs. Institutional Repository Policy Statement

\title{
RaY
}

Research at the University of York St John

For more information please contact RaY at ray@yorksj.ac.uk 


\section{An ontological framework for English}

Christopher J Hall, York St John University

\section{Introduction}

What is there in the world that we refer to as 'the English language'? Is it more than one thing? If so, how many? And what is their ontological status? For those of us engaged in researching and teaching what we call English, these are fundamental questions, yet they are seldom posed. In addressing them explicitly here, I aim to provide academics, teachers, and policymakers with some conceptual tools and arguments for a deeper reflection on the nature of English, with a view to ultimately benefiting learners and users.

In this chapter I propose that 'English' corresponds to a series of ontological categories and types, pertaining to different but related (sometimes coordinated) entities, which are significant for language learning, teaching, and assessment in different ways and to different degrees. I don't claim that the framework is exhaustive or the only one possible; instead, I adopt the nonessentialist position that conceptualizations of things are useful only in certain contexts and for certain purposes (Janicki, 2006). Furthermore, my approach is that of an applied linguist, not a philosopher of language, and accordingly I draw only sporadically and superficially on the extensive philosophical body of work on the topic (cf. Santana, 2016, for a recent example). I am interested in how English is conceived by linguists, language educators, and laypeople, not by metaphysicians. So although I appropriate ideas and terminology from this scholarship, I have in mind the 'ordinary understandings' of English which underpin the research agendas, educational practices, and public discourses associated with English learning, teaching, assessment, and use. Although my proposals are theory-engaged, they are not here theory-committed. Several of the conceptualizations of English I address derive from or are consistent with (often competing) orientations in $20^{\text {th }}$ and $21^{\text {st }}$ century linguistics and applied linguistics, but it is not my intention to advocate one over another, even though I am sometimes critical in my assessment of their claims.

My point of departure is the polysemy of the word English. The noun refers to both the people of England ('the English') and a language which was originally used only by these people, but is now used by many more ('English' and 'Englishes'). It is a nominalization of the adjective English, derived from England, 'the land of the Angles'. Taking this polysemy as the key premise, I will be claiming that English, when used in relation to language, labels types of entities associated with two ontological categories, both of which are social institutions (Searle, 1995). One set of types sits within the ontological category of the 'LANGUAGE CAPACITY', the species property for linguistic representation and communication. Within this ontological category (henceforth indicated in SMALL CAPITALS), English is a set of instantiations of the broader capacity. Understood thus, English is something we need not be aware of: it is a set of cognitive and social resources, processes, and products which would exist even if we had no name for it, and which in practice mixes freely in multilingual users with other linguistic (and non-linguistic) resources, processes, and products in the construction and communication of meaning. 
The second set of ontological types is socially constructed on the basis of the contemplation of the first set and corresponds to the conceptualizations underpinning value-laden ideologies of English (cf. Sharpe, 1974; Canagarajah, this volume, Section 4). I contend that the construals of English in this set are all directly or indirectly derived from the process of collective identification (Jenkins, 2004) holding at the level of NATION. Very recently in the evolution of the species, consciousness of particular instantiations of the LANGUAGE CAPACITY (languages in the plural) contributed to the social construction of nations, and this consciousness was in turn recruited as a constitutive element of them, to the extent that several specific instantiations of the LANGUAGE CAPACITY so recruited came to share the name of the nations they were associated with. In this sense, 'English' (the language) is something instantiating Englishness, a monolithic property of the NATION England, rather than a 'plurilithic' manifestation of the LANGUAGE CAPACITY. This conceptualization was accompanied by the social construction of a fixed code, 'Standard English', leading to dichotomies of correctness and accuracy.

In line with ideas propounded by Integrational Linguists (e.g. Harris, 1981) and critical applied linguists (e.g. Makoni and Pennycook, 2007), I will suggest that understandings of English provided within linguistics and purveyed in schools are derived from, conditioned by, or defined with reference to, this second ontological category, rather than directly from the first. Such understandings are now, more than ever, open to critique. The times and spaces we live in are radically different from those of the period of several centuries over which English as a national fixed code emerged (cf. Wright, 2015). The unique identification of the English language with the English nation has long since disappeared, and English is a global phenomenon. But the association lives on in our ontological commitments. For the benefit of L1 and L2 learners and users, these commitments need to be explicitly recognised and critically assessed.

The chapter is organized as follows. In Section 2, I develop the ontological taxonomy I have previously used to tease apart the concepts expressed by the word language, in applied linguistics (Hall, 2013), in TESOL (Hall et al., 2017b), and in non-native usage (Hall et al., 2017a; Hall, 2018). The following two sections map the entity types identified in the taxonomy onto English as constituted by the two sets of resources, processes, and products identified above. Thus, Section 3 deals with English as instantiations of the LANGUAGE CAPACITY, and Section 4 with these instantiations contemplated as direct or indirect manifestations of collective identification with the English NATION. In Section 5, I use the entities mapped in the framework to critically assess how English is treated as a subject in educational contexts. Section 6 provides a brief conclusion.

\section{An ontological taxonomy for language}

The taxonomy for language that I have been developing, only briefly sketched in the publications cited above, comprises eight ontological types. In Hall et al. (2017b), these eight types were grouped into four domains: cognitive, notional, expressive, and social (see Figure 2.1). These domains should not be taken as constructs of a rigorous ontological theory, but rather as suggestive markers of where language can be construed as existing, in ways which together permeate the human condition. The four domains are intended to mark out aspects of human experience in the following ways. The cognitive domain captures 
entities and processes which are understood to exist by virtue of their development and operation in the human mind (e.g. visual processing and episodic memory). The expressive domain embraces those physically manifested products of intentional mental processes which may be understood as signifying or indexing meanings in more or less highly structured ways (e.g. gestures and nonverbal interjections). The notional domain contains entities which exist as theoretical constructs, models, taxonomies and the like, often elaborated in formal systems, consciously devised to describe and/or explain entities in other ontological domains (e.g. calculus and Linnaean taxonomy). Finally, the social domain includes all those entities, properties, relations, and processes which are understood to exist at the level of groups of individuals and the relations between them (e.g. trade and choral singing).

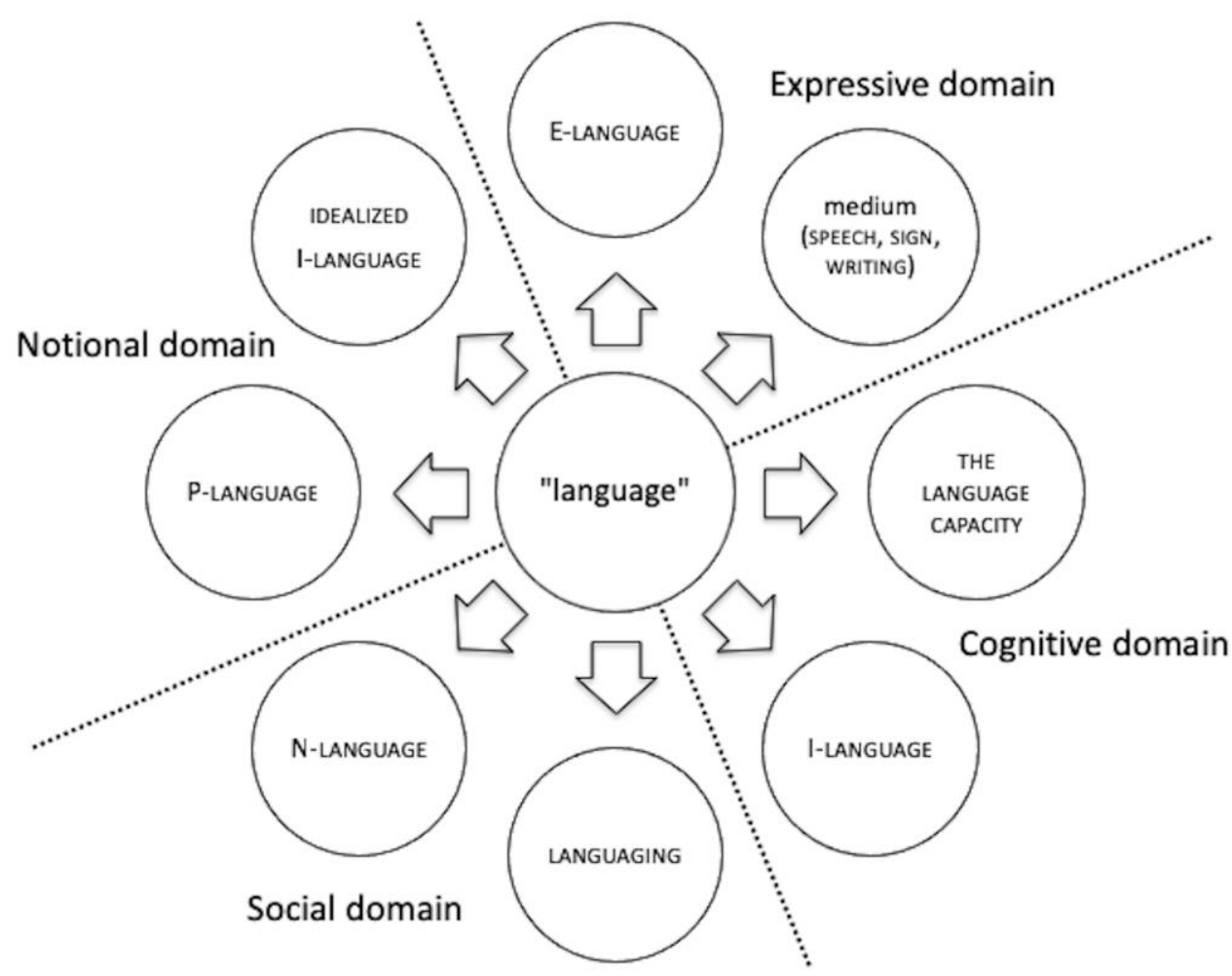

Figure 2.1: An ontological framework for language (Hall, 2013; Hall et al., 2017)

In this chapter, I introduce a further parameter of ontological categorization, which distinguishes between English as resource, process, and product. First, though, I describe each conceptualization of language in turn.

\subsection{The cognitive domain}

In the cognitive domain, the general species capacity (the 'LANGUAGE CAPACITY') is distinguished from its instantiation in individual minds ('I-LANGUAGE'). This distinction is a useful starting point for understanding how English language is conceptualized, since it captures two poles of a continuum on which English is commonly understood to be situated: 
somewhere between language as a general phenomenon and as individual linguistic resources.

\subsubsection{The LANGUAGE CAPACITY}

One way of conceptualizing language is as the species property for linguistic representation and communication which develops naturally in humans but not in other animals, even if exposed to similar environments and experiences. I call this entity 'the LANGUAGE CAPACITY'. Whether the capacity is innate and specifically linguistic (Chomsky, 1986) or emerges from more general predispositions (Tomasello, 2003), it is clearly heritable and is physically located in the mind/brain, rather than the vocal tract or hands, for example. Because it holds at the level of the species, it is universal, so corresponds to the non-count noun language.

\subsubsection{I-LANGUAGE}

According to another common understanding, language is the actual grammar, lexis, phonology, etc., that we each carry around in our heads. Despite disagreement about innateness, linguists agree that the capacity is realised in individual cognitive resources, ultimately represented in neural circuits, which develop through experience. Without sharing his specific ontological commitments, I have adopted Chomsky's (1986, pp. 21-46) term 'I-LANGUAGE' (internalized language) to refer to these instantiations of the LANGUAGE CAPACITY. This conceptualization matches the notion of 'idiolect', and for some linguists it is the only way to understand how language exists. Hall Jr. (1985, p. 353), for example, asserted that "all phenomena of language exist only in the 'know-how' [...] of individual speakers, i.e., in their idiolects. [...] Each idiolect exists only in the brain of the speaker who uses it". English as a property of individual minds is addressed in 3.1.

\subsection{The expressive domain}

Beyond biology and cognition, language can be understood as utterances and texts, in what I call the expressive domain. Here we can distinguish between: (a) linguistic expression, i.e. meaningful words, often in grammatically organized sequences, for which I again adopt a term introduced by Chomsky (1986, pp. 19-21): 'E-LANGUAGE' (externalized language); and (b) physical expression in one of three mediums: acoustically in SPEECH, or visually in SIGN and WRITING.

\subsubsection{E-LANGUAGE}

I-LANGUAGE is concerned with the potential in the brain for assembling utterances and texts. But we can also conceptualize language as the linguistic actualizations of this cognitive potential, as products of the social processes people engage in: the phonological and lexicogrammatical structures activated and articulated in language production. Hence, language can be conceived in terms of linguistic expressions, the products of I-LANGUAGES, in use as tokens (specific instances) or in usage as types (across a genre, for example). These products, for which I use the term E-LANGUAGE, may be potential or real, and if the latter, recorded (in the form of transcriptions, documents, corpora, etc.) or unrecorded. 


\subsubsection{Medium}

Language as the physical tokens of E-LANGUAGE (i.e. as acoustic or visual signals) is a matter of the medium that linguistic expressions take (as SPEECH, SIGN, or WRITING). So when someone's language is described as slow or high-pitched, what is being referred to is the physical expression, independent of its linguistic properties. SPEECH, SIGN or WRITING have no intrinsic meaning; they are physical entities that enable meaning only when processed as ELANGUAGE using I-LANGUAGE resources.

\subsection{The notional domain}

For theorists concerned with describing the structural patterns they observe in samples of ELANGUAGE which are derived from similar I-LANGUAGES, languages can be conceived as abstract systems of meaning-bearing units and the regularities according to which they are combined and interpreted. As such, they exist as theoretical constructs in what I call the notional domain, independent of actual instantiations in minds and events. This scholarly understanding of language has dominated education since classical times, and is the one with which mainstream linguistics has, in practice, been most concerned. A distinction can be made between language as an abstraction from I-LANGUAGE, and language as an abstraction from E-LANGUAGE. I call the former 'IDEALIZED I-LANGUAGE' and adopt Chomsky's term 'P-LANGUAGE' (1986, p. 33) for the latter.

\subsubsection{IDEALIZED I-LANGUAGE}

Although Chomsky (1986) stresses the cognitive nature of language as an individual mental property, actual accounts of I-LANGUAGE within generative linguistics are based on intuitions of 'grammaticality' which are assumed to hold across speakers. A working assumption is that there are separate language systems (grammars) which distinguish groups of ILANGUAGES (and therefore groups of people). Chomsky, (1986, p. 27), for example, refers to "a system of rules, English, an I-language". A similar assumption holds in other cognitivelyoriented theoretical frameworks such as usage-based linguistics (cf. Eskildsen, this volume). I use the term IDEALIZED I-LANGUAGE to refer to any abstraction from a set of similar ILANGUAGES to a language system assumed to be shared by a specific group of speakers.

\subsubsection{P-LANGUAGE}

In one ordinary conceptualization, languages exist as abstract entities, independent of individual minds or behaviours, but inferable from the products of those behaviours. This is P-LANGUAGE, where the ' $P$ ' refers to the Platonic notion of abstract entities like numbers, not locatable in space and time. Just as numbers can be related in systems which are independent of actual things or events in the world (e.g. $2+2=4$ ), so language(s) can be seen as abstract systems which exist apart from specific mental states of individuals (ILANGUAGE) and the products of their behaviours (E-LANGUAGE). This ontological status is apparent in Saussure's assertion that "[a] language [langue] is not complete in any speaker; it exists perfectly only within a collectivity" (1916, pp. 13-14). I argue in 4.2 that most 
linguistic descriptions of 'the English language' are (inevitably) describing a P-LANGUAGE abstraction, rather than I-LANGUAGE or its actualization E-LANGUAGE.

\subsection{The social domain}

Perhaps most commonly, people conceptualize language as an inherently social phenomenon, pertaining to group identity and activity. This is particularly so when ways of using language are associated with social groups perceived as unified at the level of nation, a conceptualization I call 'N-LANGUAGE'. More broadly, language exists to serve social functions, and so can be conceptualized (but less commonly so) as itself a social process or practice, rather than a national attribute or a cognitive/biological phenomenon (cf. Pennycook, 2010). I use the term 'LANGUAGING' for this sense. These are both ways of construing language in the social domain, as a constitutive element of group beliefs and behaviours.

\subsubsection{N-LANGUAGE}

Perhaps the most widely-held 'folk' understanding of language is in the sense of named languages, monolithic linguistic systems, typically thought of as being used (more or less well) by monolingual citizens of a nation from which the language name often derives. This is what I have called N-LANGUAGE (Hall, 2013), where the ' $N$ ' suggests national, named, native, and normed. The key role of language in the emergence of modern conceptions of the nation has been noted by political scientists (e.g. Anderson, 1983; Hobsbawm, 1992) and critically discussed by linguists and applied linguists (e.g. Haugen, 1966; Harris, 1981; Joseph, 2004; Makoni and Pennycook, 2007).

N-LANGUAGE is governed by norms at the level of linguistic form (pronunciation, spelling/punctuation, lexis, and grammar), such that certain forms are prescribed as correct (part of 'the language') and others not. The norms are regulative rather than constitutive (Searle, 1969, pp. 33-37), with social sanctions attached for non-compliance (e.g. stigmatization for unstandardized language use). Haugen (1966, p. 928) argued that this relatively recent conceptualization of language was a natural consequence of the national ideal which "demands that there be a single linguistic code by means of which [communication within the nation] can take place". This 'single linguistic code' is the socalled 'Standard Variety', which comes to be understood as 'the language' itself, excluding other varieties such as regional or social dialects. With a single code comes the possibility of accuracy judgements (correct/incorrect, compliance/non-compliance). The consequences of this for the ontology of English is discussed in 4.1 and, for English as a subject in education, in section 5 .

\subsubsection{LANGUAGING}

At a more fundamental social level, language can be understood not in terms of abstract symbolic systems construed as components of group identity (N-LANGUAGE), but as sociallyembedded processes (actual communication). Language doesn't just encode referential meanings, but actually does things - it has performative and indexical functions, changing social reality through speech acts (Searle, 1969), and signalling social solidarity or difference 
through "acts of identity" (Le Page and Tabouret-Keller, 1985; my emphasis). According to Searle (2010, p. 85), "[l]anguage doesn't just describe; it creates, and partly constitutes, what it both describes and creates". In this sense, then, language is constitutive of social events and the practices that underpin them. For this ontological type I have adopted the term LANGUAGING, as used, for example, by Lado (1979), Halliday (1985), Joseph (2002), Swain (2006), and Jørgensen (2008). Some scholars imply that language only exists as LANGUAGING. Johnstone (2002, p. 235), for example, argued that "[t]o think of discourse as 'language use' means imagining that 'language' could exist prior to being 'used'". I discuss the notion of English as an instantiation of LANGUAGING in 3.2.

\section{English as instantiations of the language capacity}

We are now ready to use the ontological categories and types identified for language in general to try to unpick the multiple ways in which English is understood to exist. To ensure maximal precision, I will introduce a new set of terms for entities within the general taxonomy labelled by the noun English (see Tables 1 and 2 for summaries). In this section, I address English as instantiations of the LANGUAGE CAPACITY. In the following section, I describe how these have been transformed by the conflation of language and identity into another set of senses which co-evolved with the social construction of the English nation.

Although all human beings share language in the sense of the LANGUAGE CAPACITY, it is variably rather than universally instantiated, developing different features under different local conditions. LANGUAGING works only to the extent that the I-LANGUAGES deployed in the process share features. It is only thus that English can be understood to exist independently of the national concept: as a set of instantiations of the LANGUAGE CAPACITY. In this sense, its relation to a specific territorial area, its association with a specific cultural-political group, its name, its integrity as a single system, and the degree to which it can become available to consciousness for contemplation, are irrelevant to its ontological status. The types of entity I identify in this section exist independently of what people think English is, of the existence of the word English, and indeed, of whether people are aware that English exists. The fact that two randomly selected language users may not be able to effectively engage in LANGUAGING unless they have some common I-LANGUAGE resources, demonstrates that sets of I-LANGUAGES, what people do with them (LANGUAGING), and the products they leave (ELANGUAGE in their three mediums), can be grouped together into ontological categories of their own. These categories will embrace indeterminate sets of resources, processes, and products, involving prototypical, rather than essential features. One of these sets is, in this sense, English, an instantiation (or more accurately a group of instantiations) of the LANGUAGE CAPACITY. I will call this ontological category 'L-ENGLISH' and in the following subsections I describe the four types of entity which comprise it.

\subsection{English as cognitive resource}

In one sense, English is a set of resources represented in the minds of individuals, in different quantities and degrees of entrenchment, which allows them to use certain linguistic features and constructions meaningfully with individuals who have sufficiently similar sets of resources. English in this sense includes the set of I-LANGUAGE resources which I deployed to write these sentences and a reader to interpret them, and both of us to 
produce similar ones. I will call these resources 'I-ENGLISHES'. They are plural because no two people will have identical resources (they are idiolects), and also because individuals will have multiple I-ENGLISH resources for different purposes and contexts of use. In Hall (2013) I called these 'I-REGISTERS'. Although uncommon as an object of research, aspects of English IREGISTERS are inferred in corpus studies by Mollin (2009) and Barlow (2013) for L1 users, and Hall et al. (2017a) for an L2 user. Eskildsen (this volume) reports on his own research tracing changes in L2 I-ENGLISHES through time. In LANGUAGING, these resources will be drawn on alongside others, both linguistic (e.g. in Jørgensen's [2008] 'polylingual languaging') and non-linguistic (cf. Canagarajah, this volume). I-ENGLISHES will constantly be refashioned through usage in these LANGUAGING events.

\subsection{English as social process}

In the LANGUAGING sense, English is also a set of social practices, contextualized acts or events, through which speakers realise their communicative intentions, bring states of affairs into existence, and signal social identities and relationships. I call this 'ENGLISHING' (Hall, 2014; cf. Pennycook, 2007, p. 111). In L2 learning and multilingual use, this understanding of English is especially pertinent. More people are now learning English as L2 than as L1, and increasingly are languaging with other L2 learners and users, who regularly have different L1s. Such lingua franca uses of English show considerable diversity in the depth and breadth of the I-ENGLISH resources deployed, in the degree of overlap between them (resulting mostly from L1 influence-cf. Nakatsuhara et al., this volume), and in users' ability to deploy them automatically, without conscious effort (their degree of entrenchment; cf. Mauranen, 2012; Hall, 2018). So with fewer reliably shared conventions governing language resources, communicative strategies for L2 ENGLISHING take on particular significance. Empirical studies suggest that miscommunication is rarer than one might expect (cf. Seidlhofer, 2011, ch. 5). Some who research and write about English in lingua franca mode have argued that the unstable linguistic forms involved imply that this kind of English only exists in LANGUAGING. Canagarajah (2007, p. 928), for example, claims that "L[ingua] F[ranca] E[nglish] is not a product located in the mind of the speaker; it is a form of social action". As such, he argues, it is inseparable from the deployment of other semiotic resources (including other languages). See Schaller-Schwaner and Kirkpatrick (this volume) and Baker (this volume) for more on the multilingual and transcultural nature of ENGLISHING in lingua franca contexts.

\subsection{English as expressive process and product}

Another way in which English can be understood to exist as an instantiation of the LANGUAGE CAPACITY is as the set of utterances or sentences that have actually been produced in ENGLISHING events, as actualizations of I-ENGLISHES. This is English as E-LANGUAGE, covering both tokens of use (e.g. Theresa May's ten uses of the adjective phrase 'strong and stable' at Prime Minister's Questions on $26^{\text {th }}$ April 2017) and patterns of usage ('strong and stable' as a relatively common ADJ-CONJ-ADJ collocation type). When specific utterances and texts have been (or might be) produced as part of ENGLISHING, I call these (actual or potential) 'ENENGLISHMENTS'. And ENENGLISHMENTS are, of course, physically enacted through expressive processes in two mediums (SPEECH and WRITING), which leave acoustic and visible products. 
Such 'ENENGLISHINGS' will include May's phonetic tokens [strpnnsteb|l] and the corresponding orthographic tokens in written records.

Table 2.1 summarizes this first set of conceptualizations of English.

\begin{tabular}{|c|c|c|c|}
\hline \multicolumn{4}{|c|}{ L-ENGLISH } \\
\hline Resource & Process & \multicolumn{2}{c|}{ Product } \\
\hline Cognitive domain & Social domain & \multicolumn{2}{c|}{ Expressive domain } \\
\hline I-ENGLISHES & ENGLISHING & ENENGLISHMENTS & ENENGLISHINGS \\
(instantiations of I- & (instantiations of & (instantiations of E- & (instantiations of \\
LANGUAGE): Individual & LANGUAGING): Social & LANGUAGE): Linguistic & SPEECH, SIGN, or \\
phonological, & acts using I- & forms produced & WRITING): Physical \\
orthographic, and & ENGLISHES & using l-ENGLISHES in & forms produced \\
lexico-grammatical & & ENGLISHING & using I-ENGLISHES in \\
resources & & & ENGLISHING \\
\hline
\end{tabular}

Table 2.1: English as L-ENGLISH, instantiations of the LANGUAGE CAPACITY

\section{English as instantiations of Englishness}

The types of entity identified in the preceding section capture the ontological status of the linguistic resources, processes, and products which have developed in the minds and behaviours of a set of people which started with groups living in the British Isles around one and a half millennia ago. When these entities, which collectively I am calling L-ENGLISH, became subject to contemplation, and the word English was appropriated to name the result of this contemplation, then another set of entity types was created. I claim that the defining characteristic of this set is, explicitly or implicitly, identity, at the level of NATION. On analogy with forms like wizardry and devilry, I propose to call this ontological category 'ENGLISHRY': the (contemplated) practices, products, or perceived characteristics of 'the English' or, in other words, the components of English identity. It is the linguistic reflexes of ENGLISHRY which are the topic of this section. Once more, we can identify subcategories, but in a reduced set of types, namely resources in the social and notional domains.

\subsection{English as prescribed object: N-ENGLISH}

Probably the most widely accepted conceptualization of English (the 'folk ontology') is that it is the language of England, or that language as adopted/inherited by another nation, or learnt as a 'foreign language'. It has a single, standard form, prescribed through usage guides, 'the dictionary', grammar books, and-above all-educational systems (this is what Badwan, this volume, calls the 'standard' ontology). Although English is no longer uniquely tied to 'the English', the assumption of 'one language, one nation' is deeply embedded. It tends to be forgotten that English people have always spoken other languages in addition to, or instead of, English (e.g. Cornish, French, British Sign Language; cf. Barbour, 2000). And of course there have always been citizens and residents of England and other 'Anglophone' nations whose native languages are conventionally viewed as 'foreign'. The serious 
consequences of this conflation of language and nation are lived by many people on a daily basis. The 'English Only' movement in the USA, for example, has long been recognised as a socially divisive and psychologically harmful reflex of this ideological/ontological stance (Padilla et al., 1991). See Fortier (2017) for a critique of the language/nation conflation in contemporary Britain.

\subsubsection{N-ENGLISH as 'Standard English'}

There is general agreement that a major factor in how English (later British) national identity was able to be consolidated was through recognition of a unified linguistic code, spread through what Anderson (1983) called 'print capitalism'. The unified code for England (and by extension Britain and the UK) was 'Standard English', with other national varieties subsequently also being socially constructed into existence. Its formulation required codification and then prescription, as the endpoint of a process through which value is transferred from high status user groups to an autonomous linguistic system derived from their usage (cf. Le Page and Tabouret-Keller, 1985). Crowley (1991) chronicled how the endpoint was reached for English. The texts he cites, from the $18^{\text {th }}$ to the $20^{\text {th }}$ century, demonstrate how English became conceived as a single monolithic system, used correctly or incorrectly, and how the educational system became the principal mechanism for developing and perpetuating this conceptualization. Noting the polysemy of the word English, he identifies the issue of "what is to count as 'proper English' in the realm of language" with "more significant social questions, such as, "who are the proper English'?" ( $p$. 2). The texts show how the use of 'proper English' has come to serve as a proxy for its users' good morals and good citizenship, as exemplified by socioeconomic elites. For most users, English in this sense is something they may aspire to, but do not fully possess. This is particularly the case for non-native learners and users. One telling reference in Crowley's collection, which resonates especially in the current political climate, is to Henry James' assertion that immigrants are particularly guilty of 'corrupting' the language (p. 183). English in this sense is ' $\mathrm{N}$-ENGLISH', a named monolithic system, normed for the correct forms of ENENGLISHMENTS rather than the effective enactment of functions through ENGLISHING.

\subsubsection{N-ENGLISH in education}

In the early stages of its development, consciousness and contemplation of N-ENGLISH were confined to privileged elites. It was only with the introduction of generalized public education, and with it widespread literacy, that an N-LANGUAGE understanding of English became dominant (cf. Hobsbawm, 1992). In public education, it has always been a central policy that pupils who have acquired L1 I-ENGLISHES need to be further socialized into knowledge and behaviour which reflects N-ENGLISH. Most such children start schooling with I-ENGLISHES which would be described in terms of unstandardized P-LANGUAGES, i.e. resources which don't conform to N-ENGLISH norms and would be grouped together as regional or social dialects. Currently, educational authorities in England stipulate that teachers must "take responsibility for promoting [...] the correct use of standard English, whatever the teacher's specialist subject" (Department for Education, 2011, p. 11). Similar mandates exist in the USA and other 'Anglophone' nations. 
When teachers sanction (e.g. correct) L1 users because their ENENGLISHMENTS don't correspond to N-ENGLISH norms, the goal is to modify their I-ENGLISH resources. But this educational practice is based on a confusion between ontological types. N-ENGLISH is a component of identity (ENGLISHRY), a matter of social conformity, rather than effective communication (part of L-ENGLISH). By casting English in terms of correctness, rather than social conformity, teachers automatically delegitimize (as incorrect) their pupils' own ILANGUAGE resources and LANGUAGING practices (cf. Cunningham, this volume), whether these are mono- or multilingual (regrettably, linguists' use of the term non-standard, as opposed to unstandardized, reinforces this for the former; cf. Sharples, this volume, on the latter). If conformity with 'Standard English' is to be on the curriculum, then, my ontological analysis suggests that it should be presented not in terms of accuracy, but as an (arguably desirable, perhaps necessary) attribute for socialization into broader (national) identity structures. See 5.1 for more on this, and Harder, this volume, for an alternative perspective.

\subsection{English as described object}

I pointed out in 2.3 and 2.4 that in describing languages, linguists abstract away from ILANGUAGES and E-LANGUAGE to systems assumed to hold at the level of unified communities of users, usually with the ontological status of P-LANGUAGE. I would now like to argue that, after the ontological onion skins have been stripped away, linguists' descriptions of 'the English language' are manifestations of ENGLISHRY, conditioned by the N-LANGUAGE notion of 'Standard English' and only indirectly reflecting aspects of L-ENGLISH (cf. Milroy, 2001; Armstrong and Mackenzie, 2013, ch. 2). Conceptualizations of English within linguistics are not themselves instances of N-LANGUAGE, because they involve what are assumed to be the constitutive norms of I-ENGLISH or the regularities holding acrosS ENENGLISHMENTS, rather than regulative norms imposed on the basis of preconceived notions of correctness. But, as the next section shows, linguistic descriptions of English reinforce the ordinary belief that unstandardized varieties may not be part of 'the language' (Haugen, 1966, p. 924). I will call such conceptualizations of English 'P-ENGLISH' (cf. Chomsky, 1986, p. 33) when viewed as abstractions from ENENGLISHMENTS, and 'IDEALIZED I-ENGLISH' when viewed as abstractions from I-ENGLISHES.

\subsubsection{P-ENGLISH and IDEALIZED I-ENGLISH}

A typical P-ENGLISH conceptualization can be found in Huddleston and Pullum's (2002) The Cambridge grammar of the English language, which sets out to describe "the linguistic system itself" (p. 2), taken to be "modern Standard English". Data for the description come from the authors' intuitions and those of native-speaker consultants, corpora, dictionaries, and other grammars. There is no claim to psychological reality, but there is an assumption that a single system exists, for which constitutive rules are provided. Equally, generativists have sought to describe 'the grammar of English', and again their accounts are clearly filtered through assumptions about grammaticality in a monolithic system, this time as IDEALIZED I-ENGLISH. One such account is Haegeman and Guéron's (1999) English grammar: A generative perspective, based on native-speaker grammaticality judgements and using data only from "formal English". The authors' stated intention is "to formulate part of the grammar of English" (p. 17, my emphasis). 
Another kind of linguistic description conditioned by N-ENGLISH is that based exclusively on samples of ENENGLISHMENT data, represented in corpora, typically from thousands of different writers and speakers. One well-known example is Biber et al.'s (1999) Grammar of spoken and written English, the result of an analysis of over 40 million words drawn from several registers (types of ENGLISHING). The authors state that one of their major goals is "to describe the patterns of variation that exist within standard English" (p. 18). The "brief survey of nonstandard features" they refer to (p. 20) takes up four of the 1125 pages of the volume. Although differing from traditional and generativist linguistics in terms of methodology and evidence, the conceptualization of English appears to be comparable, limited to what is taken a priori to be 'Standard English', rather than sampling across the much broader range of actual ENENGLISHMENTS. Such descriptions represent P-ENGLISH abstractions conditioned by $\mathrm{N}$-ENGLISH, and therefore again as instantiations of ENGLISHRY.

\subsubsection{L2 Englishes}

Across the approaches and practices discussed so far, it is tacitly assumed that English 'belongs' to native speakers alone (cf. Wicaksono, this volume). When construed to include those who use English as an L2, most notably in the World Englishes framework, the 'native speaker' element of N-ENGLISH is discarded. Yet the other elements of N-ENGLISH are preserved: Pennycook (2007, p. 107), for example, suggests that 'the concept of World Englishes does little more than pluralise monolithic English'. So-called 'Outer Circle' Englishes are viewed as named, national systems which follow their own norms, such as Indian English, Kenyan English, etc. (cf. Davis, 2006). Many 'Expanding Circle' Englishes (e.g. China English, Mexican English) are treated similarly. Investigation into English(es) used in lingua franca contexts has exposed many of the 'hidden' ontological commitments to NENGLISH in mainstream linguistics. But even in English as a Lingua Franca (ELF) studies, there is evidence of an underlying P-ENGLISH interpretation of the phenomenon. Initial presentations of ELF implied its existence as a variety of English, a "language system" (Seidlhofer, 2001, p. 146). And even after moves to reconceptualize it as a kind of ENGLISHING, in line with Canagarajah's (2007) arguments, there is still a tendency to present ELF in ways which invite reified P-LANGUAGE conceptualizations (cf. Mortensen, 2013; Harder, this volume). Section 5.2 below discusses the practical implications for $L 2$ learning and use of the ontological confusion underlying monolithic views of English.

Table 2.2 summarizes the ontological categories of English identified in this section.

\begin{tabular}{|c|c|c|}
\hline \multicolumn{3}{|c|}{$\begin{array}{l}\text { ENGLISHRY } \\
\text { (socially constructed components of } E\end{array}$} \\
\hline \multicolumn{3}{|c|}{ Resource } \\
\hline Social domain & Notione & domain \\
\hline $\begin{array}{l}\text { N-ENGLISH } \\
\text { (a social construction of L- } \\
\text { ENGLISH): essentially, the } \\
\text { named, national system of } \\
\text { regulative norms known as } \\
\text { 'Standard English' }\end{array}$ & $\begin{array}{c}\text { IDEALIZED I-ENGLISH } \\
\text { (an instantiation of IDEALIZED } \\
\text { I-LANGUAGE): theorized } \\
\text { constitutive norms for a } \\
\text { linguistic system abstracted } \\
\text { from I-ENGLISHES, but }\end{array}$ & $\begin{array}{c}\text { P-ENGLISH } \\
\text { (instantiations of P- } \\
\text { LANGUAGE): theorized } \\
\text { constitutive norms for a } \\
\text { linguistic system abstracted } \\
\text { from ENENGLISHMENTS, and } \\
\text { sometimes correlated with }\end{array}$ \\
\hline
\end{tabular}




\begin{tabular}{|c|c|c|}
\hline & $\begin{array}{c}\text { implicitly conditioned by N- } \\
\text { ENGLISH }\end{array}$ & $\begin{array}{c}\text { types of ENGLISHING, but } \\
\text { implicitly conditioned by N- } \\
\text { ENGLISH }\end{array}$ \\
\hline
\end{tabular}

Table 2.2: English as linguistic manifestations of ENGLISHRY

5 English as subject

The emergence of English as a manifestation of ENGLISHRY gave rise to, and subsequently has been sustained by, a set of subjects studied in educational institutions, also called English (the topic of Part $\mathrm{C}$ and Chapter 11, this volume). These subjects involve the study of $\mathrm{N}$ ENGLISH and P-ENGLISH as L1 resources (5.1) and as L2 resources (5.2), and the study of literature written using I-ENGLISHES (5.3). Figure 2.2 shows their relationship with the ontological types described in sections 3 and 4 . In this final section, I suggest that educational objectives and practices regarding English might be usefully critiqued by applying the framework presented above.

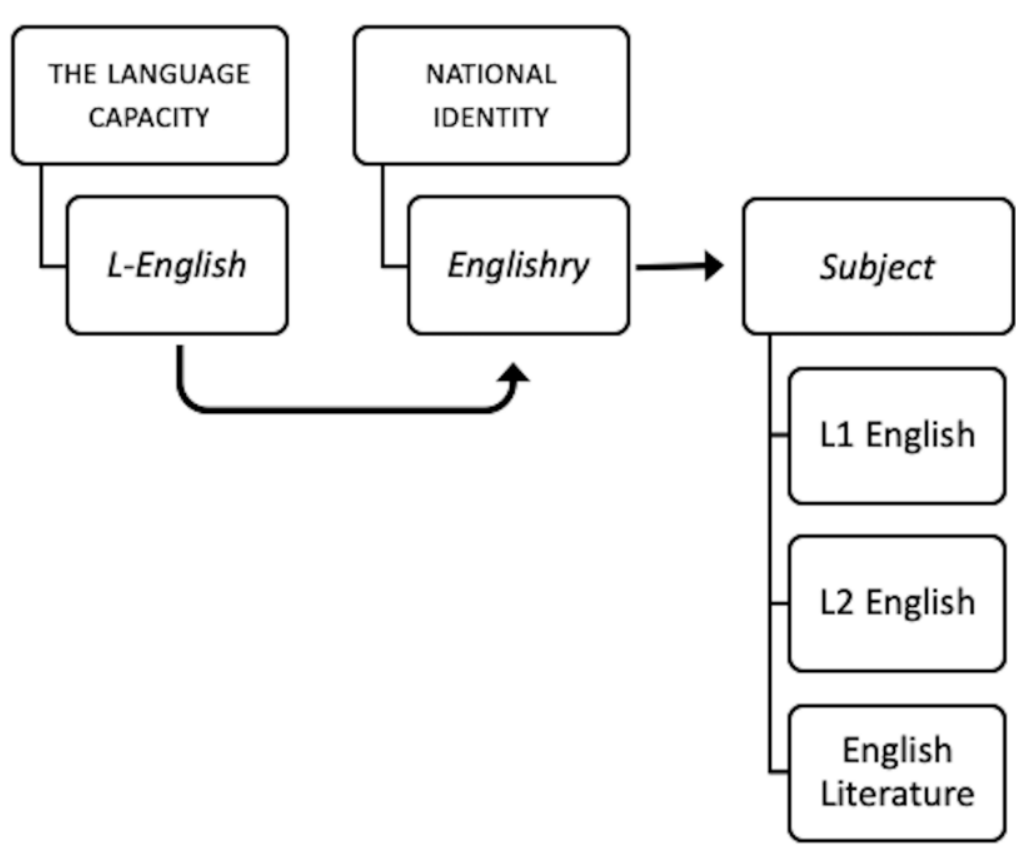

Figure 2.2: From L-ENGLISH to English as subject

\subsection{English as subject for L1 users}

When children acquiring and using English as an $\mathrm{L} 1$ are required to study the regularities of 'Standard English' deliberately, as part of a school subject, there is once again an ontological 
conflict. Educational policy, assuming N-ENGLISH, fails to appreciate that the P-LANGUAGE descriptions of 'Standard English' taught in schools can be deliberately learned, but not, like I-LANGUAGE, naturally acquired. Instruction, as opposed to ENGLISHING experience, will result in conscious metalinguistic knowledge of a set of P-ENGLISH facts. In the brain, the unconscious I-LANGUAGE resources drawn upon during LANGUAGING are associated with two kinds of memory system: declarative and procedural (cf. Ullman, 2014). Declarative systems store arbitrary facts, including vocabulary. Procedural systems store automatized (entrenched) patterns, including grammatical constructions, which are used effortlessly for fluent communication. All consciously learned and deliberately accessed knowledge, however, whether lexical or syntactic, is controlled by declarative memory. Knowledge about English (e.g. about P-ENGLISH) is stored there. So for most pupils who have limited previous experience of ENENGLISHMENTS which accord with N-ENGLISH norms, the English they study at school will not become the entrenched procedural I-REGISTER they need for national contexts of ENGLISHING. What they learn as declarative knowledge will be deployed deliberately, and in many cases only laboriously. Of course, extensive involvement in ENGLISHING in appropriate contexts can result in I-REGISTERS which correspond to N-ENGLISH norms, but this cannot be guaranteed. And it makes little sense to expect, as England's current national curriculum does, that young children should deliberately study P-ENGLISH descriptions of 'Standard English' before actually acquiring the I-LANGUAGE features corresponding to it through ENGLISHING (cf. UKLA and Owen Education, 2016; Goddard, this volume).

\subsection{English as subject for L2 learners and users}

For L2 English, ontological confusion also stymies effective educational practice. In L2 English classrooms, the target for learning and the model for teaching are almost always 'Standard English', and accuracy (the extent to which learners' ENENGLISHMENTS follow PENGLISH rules derived from N-ENGLISH regulative norms) is still the main parameter of assessment (although see Harsch and Nakatsuhara et al., both this volume). The desired outcome of L2 English study is, however, normally professed to be communicative competence, i.e. fluent and effective ENGLISHING, but this requires I-ENGLISH resources in procedural memory (Hall, 2014). As a subject, therefore, L2 English is the converse of L1 English: children in L1 environments first acquire a dispreferred (unstandardized) I-ENGLISH at home and are expected to replace it at school with learned N-ENGLISH; L2 learners first learn about 'correct' N-ENGLISH and are then expected to acquire a usable I-ENGLISH. As with L1, it is possible, under the right circumstances (exposure, motivation, etc.), for learners to achieve sufficient conscious control of N-ENGLISH facts in declarative memory to be able to deploy them effectively in interaction, and perhaps to develop an unconscious I-ENGLISH in procedural memory which matches the norms of N-ENGLISH (and many learners may want or need this: see Kohn, 2011; Harder, this volume). But for most L2 learners, the I-ENGLISH they develop will inevitably be influenced by their own L1, by the learning processes they engage in, and by the uses to which they put their resources. This I-ENGLISH is English, but just like most L1 I-ENGLISHES, obeys its own regularities rather than being governed by N-ENGLISH norms (cf. Lemhöfer et al. 2014 for neuropsychological evidence supporting this view). It thus makes little sense to insist on accuracy in those norms (Page, this volume), unless 'Standard English' ENENGLISHMENTS are required or desired for social conformity, e.g. for study in English-medium higher education institutions (Swan, 2017). 


\subsection{English as literature}

Finally, the term English is used to refer not to the study of any of the ontological types described here, but to the study of literary texts, examples of ENENGLISHMENTS produced deliberately as creative/artistic products using I-ENGLISHES. Here the role and status of NLANGUAGE is perhaps most palpable, because the 'canon' is viewed as a source and model of its legitimacy, as observed for example in dictionary citations and good usage guides. I won't say more about this issue here, except to suggest that maybe it's time to rename the subject, in order to avoid the implication that the essence of L-ENGLISH, or of ENGLISHRY, is to be found in literary form. English Music or English Art don't appear on any school curriculum I am aware of, so perhaps it's time for just Literature? See Goodwyn and Roberts (both this volume) for extended discussion of English (literature) as a school subject.

\section{Conclusion}

My aim in this chapter has been to highlight the ways in which the fundamental elements of human language(s) as instantiations of the LANGUAGE CAPACITY have been reinterpreted through the lens of collective identification with NATION, to give rise to the 'folk ontology' of English as a manifestation of ENGLISHRY. Ordinary uses of the word English reflect deepseated beliefs about the nature of language and its relationship with national identity. These beliefs have been embedded through the operation of hegemonic cultural forces, acting especially through education systems, to maximize "internal cohesion [and] external distinction" (Haugen 1966, p. 928). The N-LANGUAGE manifestation of this deliberate contemplation and construction of 'the language of the English' is the monolithic social construct 'Standard English'. This construct is inevitably accompanied by notions of correctness and accuracy (and therefore error and failure) in schooling and society at large. I argued in this chapter that it has also influenced linguistic understandings of the notions of 'grammaticality' and 'non-standardness', in that 'the English language' is typically presented in terms of P-LANGUAGE (or IDEALIzed I-LANGUAGE) descriptions of the 'standard variety'. It is, then, unsurprising that for many teachers of English, both as L1 and L2, the subject they teach is understood in terms of P-ENGLISH, and this is what learners expect. The fact that learners can and will only acquire I-ENGLISHES, and that only I-ENGLISHES can be used effortlessly and effectively in ENGLISHING, is mostly unappreciated.

Readers may not be persuaded by my interpretation of how the ontological categories and types I propose underpin beliefs and practices in English teaching and assessment. But the framework should at least provide some points of reference for examining their own ontological commitments regarding English and, particularly, for teasing apart the following:

- effective use of linguistic resources for social practices (I- ENGLISHES in ENGLISHING) vs. performance of 'proper' Anglophone identities (conformity with N-ENGLISH norms);

- actual language functions and usage (ENGLISHING and ENENGLISHMENTS) vs. knowledge of idealized language descriptions (P-ENGLISH and IDEALIZED I-ENGLISH);

- acquirable cognitive resources (I-ENGLISHES) vs. learnable metalinguistic knowledge (P-ENGLISH, N-ENGLISH);

- communicative potential and creativity (entrenched I-ENGLISHES and fluent ENGLISHING) vs. social conformity (N-ENGLISH accuracy in ENENGLISHMENTS); 
- what is out there (I-ENGLISH and ENGLISHING) vs. what one feels should be out there (NENGLISH).

I hope that the detailed anatomy of the senses of English provided above will help with this ongoing critical process.

\section{References}

Anderson, B. (1983). Imagined communities. Reflections on the origin and spread of nationalism. London: Verso.

Armstrong, N. and Mackenzie, I. E. (2013). Standardization, ideology and linguistics. Basingstoke: Palgrave Macmillan.

Barbour, S. (2000). Britain and Ireland: the varying significance of language for nationalism. In Barbour, S. and Carmichael, C. (eds). Language and nationalism in Europe (pp. 18-43). Oxford: Oxford University Press.

Barlow, M. (2013). Individual differences and usage-based grammar. International Journal of Corpus Linguistics, 18, 4, 443-478.

Biber, D., Johansson, S., Leech, G., Conrad, S., and Finegan, E. (1999). Longman grammar of spoken and written English. London: Longman.

Canagarajah, S. (2007). Lingua franca English, multilingual communities, and language acquisition. The Modern Language Journal, 91, 923-939.

Chomsky, N. (1986). Knowledge of language. New York: Praeger.

Crowley, T. (1991). Proper English? Readings in language, history and cultural identity. London: Routledge.

Davis, D. R. (2006). World Englishes and descriptive grammars. In Kachru, B. B., Kachru, Y., and Nelson, C. L. (eds), The handbook of World Englishes (pp. 509-525). Oxford: Blackwell.

Department for Education (2011). Teachers' standards. Guidance for school leaders, school staff and governing bodies. Online. Retrieved 27/07/17 from: https://www.gov.uk/government/publications/teachers-standards.

Fortier, A. M. (2017). On (not) speaking English: colonial legacies in language requirements for British citizenship. Sociology. DOI: 10.1177/0038038517742854.

Haegeman, L. and Guéron, J. (1999). English grammar: A generative perspective. Oxford: Blackwell.

Hall, C. J. (2013). Cognitive contributions to plurilithic views of English and other languages. Applied Linguistics, 34, 211-231.

Hall, C. J. (2014). Moving beyond accuracy: from tests of English to tests of 'Englishing'. ELT Journal, 68, 4, 376-385.

Hall, C. J. (2018). Cognitive perspectives on English as a Lingua Franca. In Jenkins, J., Baker, W. and Dewey, M. (eds). Routledge handbook of English as a Lingua Franca (pp. 74-84). London: Routledge.

Hall, C. J., Joyce, J. and Robson, C. (2017a). Investigating the lexico-grammatical resources of a non-native user of English: the case of can and could in email requests. Applied Linguistics Review, 8, 1, 35-59.

Hall, C. J., Wicaksono, R., Liu, S., Qian, Y. and Xu, X. (2017b). Exploring teachers' ontologies of English. Monolithic conceptions of grammar in a group of Chinese teachers. International Journal of Applied Linguistics, 27, 1, 87-109. 
Hall Jr., R. A. (1985). Meaning and the idiolect: The idioseme. In Jankowsky, K. R. (ed.), Scientific and humanistic dimensions of language: Festschrift for Robert Lado. On the occasion of his 70th birthday (pp. 353-359). Amsterdam: John Benjamins.

Halliday, M. A. K. (1985). Systemic background. In Benson, J. D. (ed.). Systemic perspectives on discourse: 1. Selected theoretical papers from the 9th International Systemic Workshop (pp. 1-15). New York: Ablex.

Harris, R. (1981). The language myth. London: Duckworth.

Haugen, I. (1966). Dialect, language, nation. American Anthropologist, 68, 922-935.

Hobsbawm, E. J. (1992). Nations and nationalism since 1780. Programme, myth, reality (2 ${ }^{\text {nd }}$ edn). Cambridge: Cambridge University Press.

Huddleston, R. and Pullum, G. K. (2002). The Cambridge grammar of the English language. Cambridge: Cambridge University Press.

Janicki, K. (2006). Language misconceived. Arguing for Applied Cognitive Sociolinguistics. Mahwah, NJ: Lawrence Erlbaum.

Jenkins, R. (2004). Social identity ( $3^{\text {rd }}$ edn). London: Routledge.

Johnstone, B. (2002). Discourse analysis. Oxford: Blackwell.

Jørgensen, J. N. (2008). Polylingual languaging around and among children and adolescents. International Journal of Multilingualism, 5, 3, 161-176.

Joseph, J. E. (2002). Is language a verb? Conceptual change in linguistics and language teaching. In Trappes-Lomax, H. R., \& Ferguson, G. (eds.), Language in language teacher education (pp. 29-47). Amsterdam: John Benjamins.

Joseph, J. E. (2004). Language and identity. National, ethnic, religious. Basingstoke: Palgrave Macmillan.

Kohn, K. (2011). English as a lingua franca and the Standard English misunderstanding. In de Hower, A. and Wilton, A. (eds), English in Europe today: Sociocultural and educational perspectives (pp. 71-94). Amsterdam: Benjamins.

Lado, R. (1979). Thinking and "languaging": a psycholinguistic model of performance and learning. Sophia Linguistica, 12, 3-24.

Lemhöfer, K., Schriefers, H. and Indefrey, P. (2014). Idiosyncratic grammars: syntactic processing in second language comprehension uses subjective feature representations. Journal of Cognitive Neuroscience, 26, 7, 1428-1444.

Le Page, R. B. and Tabouret-Keller, A. (1985). Acts of identity. Creole-based approaches to language and ethnicity. Cambridge: Cambridge University Press.

Makoni, S. and Pennycook, A. (Eds) (2007). Disinventing and reconstituting languages. Clevedon, UK: Multilingual Matters.

Mauranen, A. (2012). Exploring ELF. Academic English shaped by non-native speakers. Cambridge: Cambridge University Press.

Milroy, J. (2001). Language ideologies and the consequences of standardization. Journal of Sociolinguistics, 5, 4, 530-555.

Mollin, S. (2009). "I entirely understand" is a Blairism. The methodology of identifying idiolectal collocations. International Journal of Corpus Linguistics, 14, 3. 367-392.

Mortensen, J. (2013). Notes on English used as a lingua franca as an object of study. Journal of English as a Lingua Franca, 2, 1, 25-46.

Padilla, A. M., Lindholm, K. J., Chen, A., Durán, R., Hakuta, K., Lambert, W., and Tucker, G. R. (1991). The English-only movement: Myths, reality, and implications for psychology. American Psychologist, 46, 2, 120-130. 
Pennycook, A. (2007). The myth of English as an International Language. In Makoni, S. and Pennycook, A. (Eds), Disinventing and reconstituting languages (pp. 90-115). Clevedon, UK: Multilingual Matters.

Pennycook, A. (2010). Language as a local practice. London: Routledge.

Saner, E. (2015, August 7). 'I can't speak properly. I am different': do you need to speak English to be a good citizen? The Guardian. Online. Retrieved 02/05/18 from: https://www.theguardian.com/education/2015/aug/07/do-you-need-to-speak-englishto-be-good-citizen

Santana, C. (2016). What is language? Ergo, 3, 19, 501-523.

Saussure, F. de. (1916/1966). Course in general linguistics. New York: McGraw-Hill.

Searle, J. R. (1969). Speech acts: An essay in the philosophy of language. Cambridge: Cambridge University Press.

Searle, J. R. (1995). The construction of social reality. New York: Simon and Schuster.

Searle, J. R. (2010). Making the social world: The structure of human civilization. Oxford: Oxford University Press.

Seidlhofer, B. (2001). Closing a conceptual gap: the case for a description of English as a lingua franca. International Journal of Applied Linguistics, 11, 2, 133-158.

Seidlhofer, B. (2011). Understanding English as a Lingua Franca. Oxford: Oxford University Press.

Sharpe, R. A. (1974). Ideology and ontology. Philosophy of the Social Sciences, 4, 55-64.

Swain, M. (2006). Languaging, agency and collaboration in advanced second language learning. In Byrnes, H. (ed.), Advanced language learning: the contributions of Halliday and Vygotsky (pp. 95-108). London: Continuum.

Swan, M. (2017). EFL, ELF, and the question of accuracy. ELT Journal. doi: 10.1093/elt/ccx031.

Tomasello, M. (2003). Constructing a language. A usage-based theory of language acquisition. Cambridge, MA: Harvard University Press.

UKLA and Owen Education (2016). Curriculum and assessment in English 3 to 19: A Better Plan. Leicester: UKLA Publications. Online. Retrieved 29/07/17 from: https://www.nate.org.uk/file/2016/04/The-National-Curriculum-for-English-from2015.pdf.

Ullman, M. T. (2014). The declarative/procedural model. A neurobiologically motivated theory of first and second language. In VanPatten, B. and Williams, J. (eds), Theories in second language acquisition: An introduction (2nd edn, pp. 135-158). London: Routledge.

Wright, S. (2015). What is language? A response to Philippe van Parijs. Critical Review of International Social and Political Philosophy, 18, 2, 113-130. 